\title{
Synthesis of Pentasaccharide and Heptasaccharide Derivatives and Their Effects on Plant Growth
}

\author{
Hongmei Liu, ${ }^{\dagger, \S}$ Shuinong Cheng, ${ }^{\ddagger}{ }^{\S}$ Jun Liu, ${ }^{\ddagger}$ Yuguang Du, ${ }^{*}{ }^{\dagger}$ Zhinui Bai,${ }^{\ddagger}$ \\ AND YuguO Du* ${ }^{*}$ \\ The Natural Products and Glycoconjugate Research Group 1805, Dalian Institute of Chemical Physics, \\ Chinese Academy of Sciences, Dalian 116023, China, State Key Laboratory of Environmental \\ Chemistry and Ecotoxicology, Research Center for Eco-Environmental Sciences, Chinese Academy of \\ Sciences, Beijing 100085, China, and Graduate University of the Chinese Academy of Sciences, China
}

\begin{abstract}
Two oligosaccharide derivatives, $\beta$-D-Glcp-(1-6)- $\beta$-D-Glcp-(1-6)- $\beta$-D-Glcp-(1-6)- $\beta$-D-Glcp-(1-4)- $\alpha$ D-ManpOMe (1) and $\beta$-D-Glcp-(1-6)- $\beta$-D-Glcp-(1-6)- $\beta$-D-Glcp-(1-6) - $\beta$-D-Glcp-(1-6)- $\beta$-D-Glcp-(1-6)$\beta$-D-Glcp-(1-4)- $\alpha$-D-ManpOMe (2), have been synthesized efficiently using a convergent glycosylation strategy of $2+3$ and $2+5$. 1,6-Anhydro- $\beta$-D-glucopyranose, which was prepared from cotton pyrolysis, was applied as a key synthon in the synthesis, significantly simplifying the preparation. The bioassay suggested that these two oligosaccharides can both stimulate the growth of maize cultured in liquid medium at a concentration of $3 \mathrm{ppm}$.
\end{abstract}

\section{KEYWORDS: Oligosaccharide; synthesis; plant growth; maize}

\section{INTRODUCTION}

Various synthetic and naturally derived fungicides, bactericides, and antiviral agents have been used to prevent crops from infection by pathogens without deleteriously affecting their growth and ultimate harvesting. Although such compositions are effective, there have been more and more concerns from consumers regarding the potential harmful side effects of chemical agents. This, in turn, has led people to pay more attention to products of natural origin with less likely adverse side effects $(1-3)$.

Oligosaccharides, that can exert signaling effects on plant tissues at very low concentration, are termed as oligosaccharins. Some of them are elicitors for they induce a response that may help the plant resist disease, while some have effects on plant growth and development, which are described as nontraditional plant hormones such as pectic oligosaccharins and xyloglucan oligosaccharins. Despite some oligosaccharins as plant hormones are ensured, there is still an urgent need to add flesh to our skeletal understanding of oligosaccharins, including the discovery of new biological effects (4-8). Two oligosaccharides, heptasaccharide (HS) and octasaccharide (OS), were isolated from the water extract of the rhizomes of Paris polyphylla var. yunnanensis. They were identified as linear oligomers, composed of glucose and mannose residues. The structures of compounds HS and OS were elucidated, on the basis of NMR and mass

* To whom correspondence should be addressed. E-mail: duyg@ dicp.ac.cn (Yuguang Du); duyuguo@rcees.cn (Yuguo Du).

Dalian Institute of Chemical Physics, Chinese Academy of Sciences.

$\S$ Graduate University of the Chinese Academy of Sciences.

${ }^{\ddagger}$ Research Center for Eco-Environmental Sciences, Chinese Academy of Sciences. spectra analyses, as D-Glc-(1-6)- $\beta$-D-Glc-( $1-6)-\beta$-D-Glc-( $1-6)$ $\beta$-D-Glc-( $1-6)-$ Glc- $(1-6)-\beta$-D-Glc- $(1-4)-\alpha-D-M a n$ and D-Glc$(1-6)-\beta$-D-Glc- $(1-6)-\beta$-D-Glc- $(1-6)-\beta$-D-Glc- $(1-6)-\beta$-D-Glc(1-6)- Glc-( $1-6)-\beta$-D-Glc-(1-4)- $\alpha$-D-Man, respectively. Primary bioactivity testing suggests that HS and OS may have plant growth regulatory activity in plant tissue cultures $(9,10)$. We hereby describe a practical method in the preparation of HS analogues, pentasaccharide $\beta$-D-Glcp- $(1-6)-\beta$-D-Glcp- $(1-6)-$ $\beta$-D-Glcp-(1-6)- $\beta$-D- Glcp-(1-4)- $\alpha$-D-ManpOMe (1) and heptasaccharide $\beta$-D-Glcp-(1-6)- $\beta$-D-Glcp-( $1-6)-\beta$-D-Glcp-( $1-6)$ $\beta$-D-Glcp-(1-6)- $\beta$-D-Glcp-( $1-6)-\beta$-D-Glcp- $(1-4)-\alpha$-DManpOMe (2) (Scheme 1), and disclose our primary results on maize growth after treating with $\mathbf{1}$ and $\mathbf{2}$.

In our ongoing project, we found an efficient method for the synthesis of $\beta$-D-( $1 \rightarrow 6)$-linked gluco-oligosaccharides using levoglucose, which was prepared from cotton pyrolysis (11) as starting material. Thus, 1,6-anhydro- $\beta$-D-glucose (levoglucose, 3) was benzylated in DMF with benzyl bromide and $\mathrm{NaH}$ affording 1,6-anhydro-2,3,4-tri- $O$-benzyl- $\beta$-D-glucopyranose (4). Treatment of 4 with 2-propanethiol and $\mathrm{BF}_{3} \cdot \mathrm{Et}_{2} \mathrm{O}$ in refluxed $\mathrm{CH}_{2} \mathrm{Cl}_{2}$ obtained isopropyl 2,3,4-tri- $O$-benzyl-1-thio-D-glucopyranoside (5) as an $\alpha$ product in $56 \%$ yield over two steps. The small $J_{1,2}$ value $(5.5 \mathrm{~Hz})$ at $5.34 \mathrm{ppm}$ on the related ${ }^{1} \mathrm{H}$ NMR spectrum clearly indicated the correct structure of $\mathbf{5}$. Conver-

Scheme 1

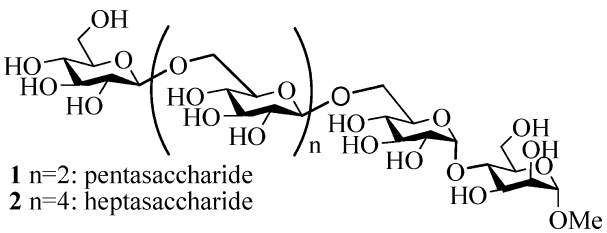


Scheme 2

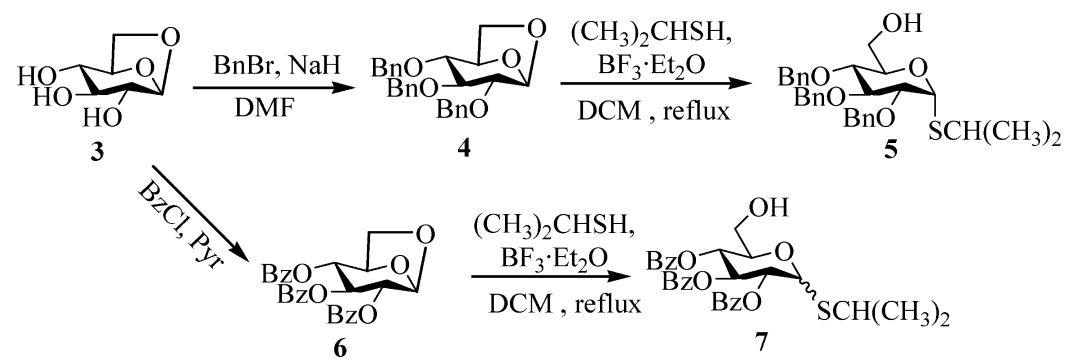

Scheme 3

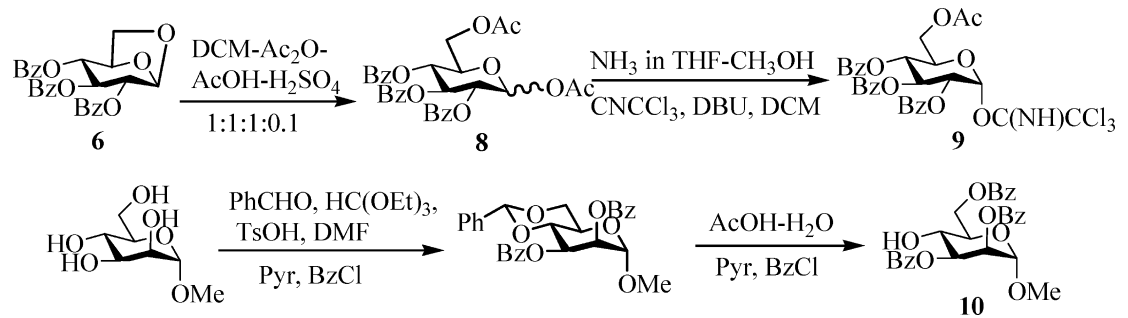

Scheme 4

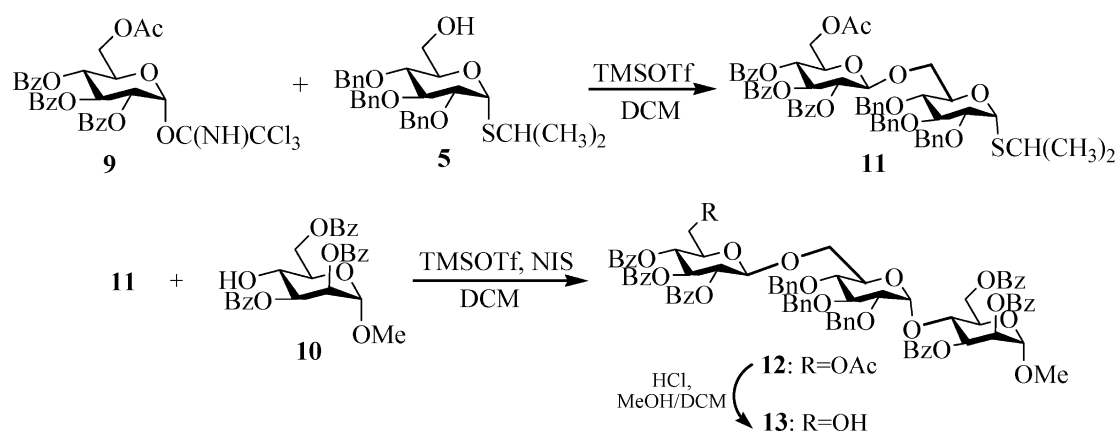

Scheme 5

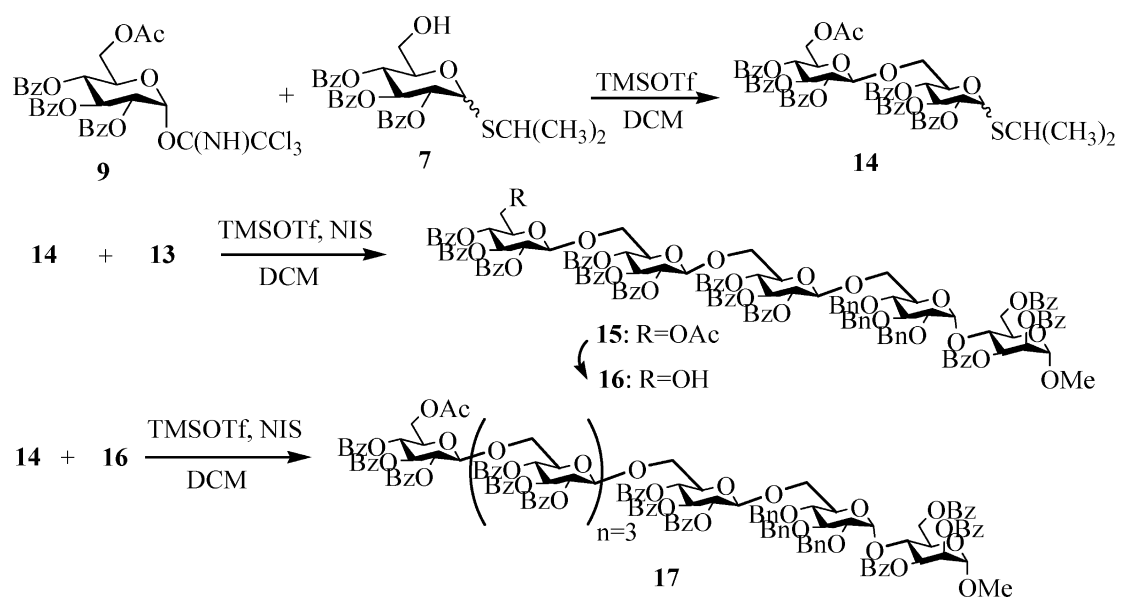

gently, compound 3 was benzoylated with benzoyl chloride in dry pyridine affording 1,6-anhydro-2,3,4-tri- $O$-benzoyl- $\beta$-Dglucopyranose (6), followed by ring opening with 2-propanethiol and $\mathrm{BF}_{3} \cdot \mathrm{Et}_{2} \mathrm{O}$ in refluxed $\mathrm{CH}_{2} \mathrm{Cl}_{2}$, which furnished isopropyl 2,3,4-tri- $O$-benzoyl-1-thio-D-glucopyranoside (7) as an $\alpha, \beta$ mixture $\left(n_{\alpha} / n_{\beta} \approx 6 / 1\right)$ in $47 \%$ yield over two steps (Scheme 2).

Acetolysis of 6 with $\mathrm{Ac}_{2} \mathrm{O}-\mathrm{AcOH}-\mathrm{H}_{2} \mathrm{SO}_{4}$ (1:1:0.1) in $\mathrm{CH}_{2} \mathrm{Cl}_{2}$ gave 1,6-di- $O$-acetyl-2,3,4-tri- $O$-benzoyl- $\beta$-D-glucopyranose (8), which was then transformed into glycosyl donors 6- $O$-acetyl2,3,4-tri-O-benzoyl-a-D-glucopyranosyl trichloroacetimidate (9) according to published methods in $91 \%$ yield over three steps (12). Methyl 2,3,6-O-benzoyl- $\alpha$-D-mannopyranoside (10) was prepared from commercial available methyl D-mannoside via
4,6- $O$-benzylidenation, benzoylation, acid hydrolysis, and regioselective 6- $O$-benzoylation in 76\% yield (13) (Scheme 3).

Condensation of $\mathbf{5}$ with $\mathbf{9}$ in the presence of a catalytic amount of trimethylsilyl trifluoromethanesulfonate (TMSOTf) in $\mathrm{CH}_{2} \mathrm{Cl}_{2}$ at $-20{ }^{\circ} \mathrm{C}$ gave desired disaccharide, isopropyl 6- $O$-acetyl-2,3,4tri- $O$-benzoyl- $\beta$-D-glucopyranosyl-( $(\rightarrow 6)-2,3,4$-tri- $O$-benzyl-1thio- $\alpha$-D-glucopyranoside (11), in excellent yield (98\%). Coupling of disaccharide thioglycosyl donor $\mathbf{1 1}$ and acceptor $\mathbf{1 0}$ in $\mathrm{CH}_{2} \mathrm{Cl}_{2}$ at $-20{ }^{\circ} \mathrm{C}$ in the presence of cocatalyst TMSOTf and $N$-iodosuccinimide (NIS), afforded the expected $\alpha$-linked trisaccharide (12) in good yield (78\%). A doublet at $\delta 5.44 \mathrm{ppm}$ in the ${ }^{1} \mathrm{H}$ NMR spectrum supports the newly formed $\alpha$-bond between glucosyl units II and III. Regioselective deacetylation 
Table 1. ${ }^{1} \mathrm{H}-\mathrm{NMR}$ Data of Compounds 5-17

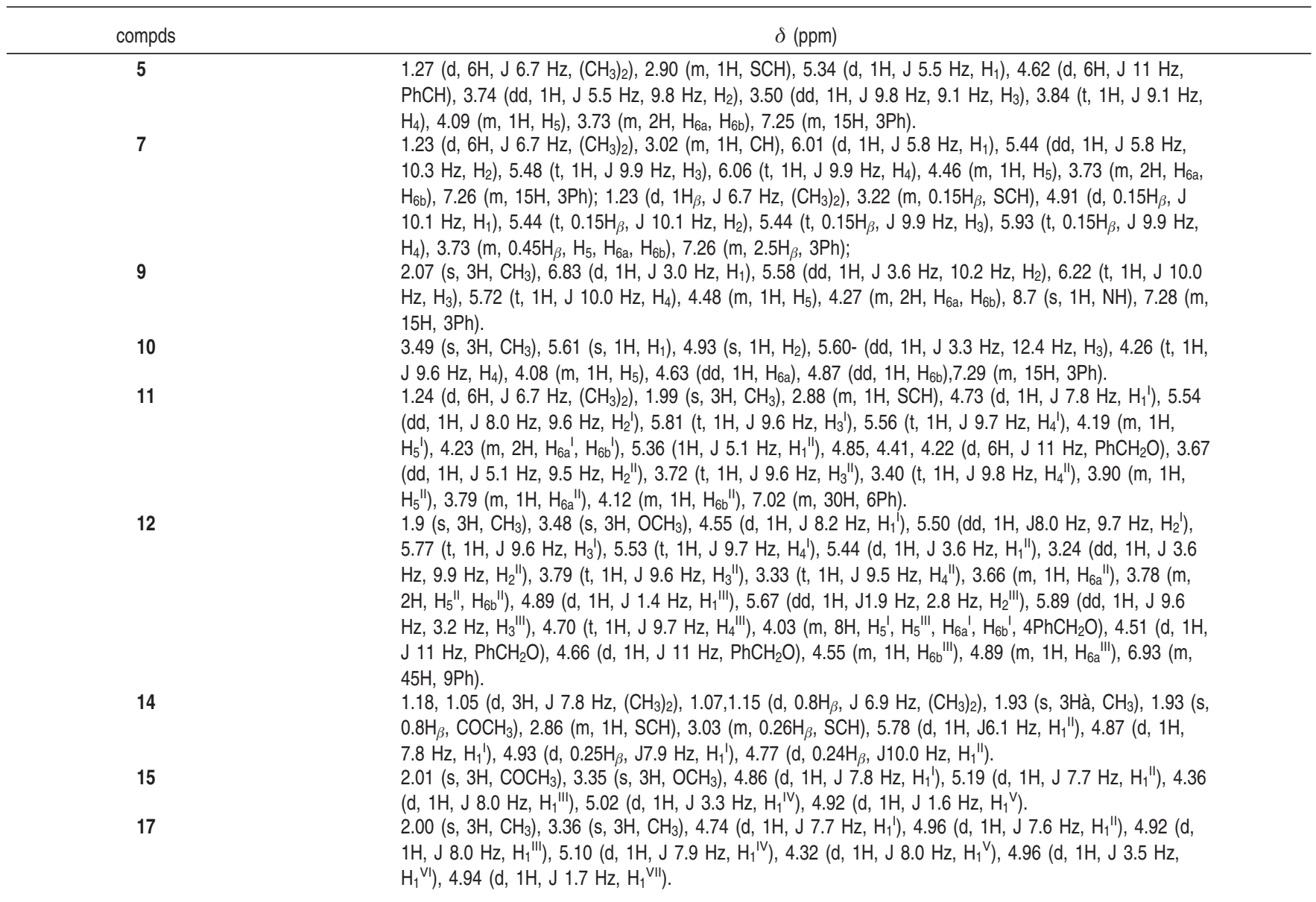

of 12 with $\mathrm{HCl}$ (gas) in $\mathrm{MeOH} / \mathrm{DCM}(1: 2, \mathrm{v} / \mathrm{v})$ gave (13) as the trisaccharide glycosyl acceptor in good yield (89\%) (14) (Scheme 4).

Condensation of $\mathbf{9}$ with 7 catalyzed by TMSOTf gave a key intermediate 6- $O$-acetyl-2,3,4-tri- $O$-benzoyl- $\beta$-D-glucopyranosyl$(1 \rightarrow 6)$-2,3,4-tri- $O$-benzoyl-1-thio-D-glucopyranoside $(\mathbf{1 4})$ in $68 \%$ yield as an $\alpha, \beta$ mixture $\left(n_{\alpha} / n_{\beta} \approx 4 / 1\right)$, which was directly used for the next reaction without further purification. Coupling of disaccharide glycosyl donor $\mathbf{1 4}$ with trisaccharide glycosyl acceptor 13 was promoted with TMSOTf/NIS in $\mathrm{CH}_{2} \mathrm{Cl}_{2}$, giving pentasaccharide (15) in an isolated yield of $80 \%$. Removal of 6-O-deacetylation from 15 as described in the preparation of 13 afforded pentasaccharide glycosyl acceptor (16). Condensa-

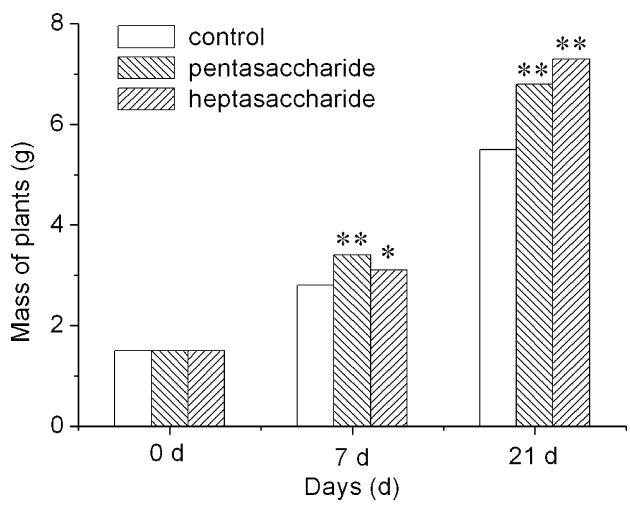

Figure 1. Mass of maize plant after exposure to oligosaccharides for one and three weeks. The results are expressed as means $(n=4)$. The asterisk $\left(^{*}\right)$ indicates a significant difference from the control group $\left({ }^{*}, p\right.$ $\left.>0.05 ;{ }^{* *}, p>0.01\right)$. tion of 14 with 16 using the same reaction conditions as those described in the preparation of $\mathbf{1 5}$ obtained heptasaccharide (17) in $83 \%$ yield (Scheme 5). Global deprotection of compounds 15 and 17 (15-17) obtained pentasaccharide 1 and heptasaccharide $\mathbf{2}$, respectively, in almost quantitative yields.

\section{MATERIALS AND METHODS}

Instruments. ${ }^{1} \mathrm{H}$ NMR and ${ }^{13} \mathrm{C}$ NMR were recorded with a Bruker ARX 400 spectrometer for the solutions in $\mathrm{CDCl}_{3}$ or $\mathrm{D}_{2} \mathrm{O}$. The chemical shifts are given in parts per million downfield from internal $\mathrm{Me}_{4} \mathrm{Si}$. Mass spectra were measured using a MALDI-TOF-MS with a-cyano4-hydroxycinnamic acid (CCA) as matrix or recorded with a VG

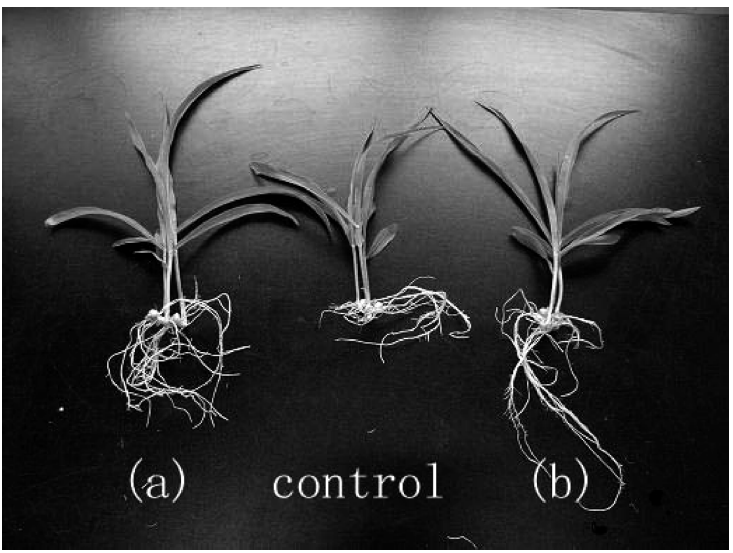

Figure 2. Effect on the growth of maize plants treated with oligosaccharide for one week. The control is nutrient media, (a) is nutrient media plus $3 \mathrm{ppm}$ pentasaccharide, and $(\mathrm{b})$ is nutrient media plus 3 ppm heptasaccharide. 


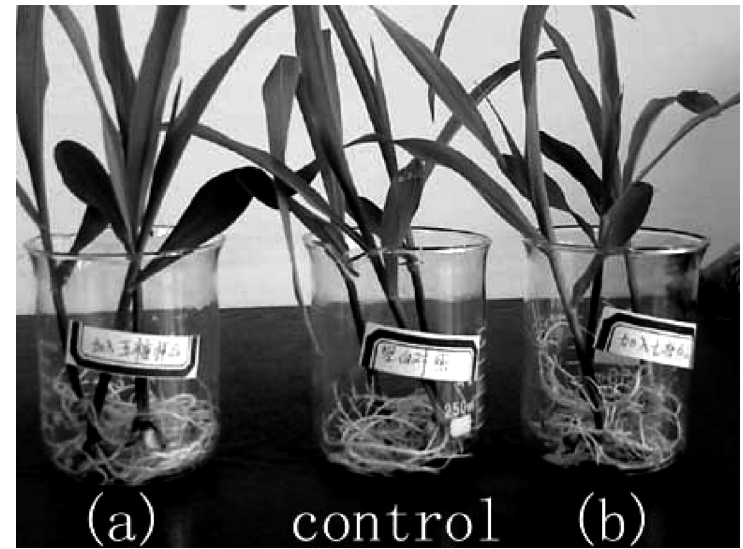

Figure 3. Effect on the growth of maize roots treated with oligosaccharide for three weeks. The control is nutrient media, (a) is nutrient media plus $3 \mathrm{ppm}$ pentasaccharide, and (b) is nutrient media plus $3 \mathrm{ppm}$ heptasaccharide.

\section{Scheme 6}
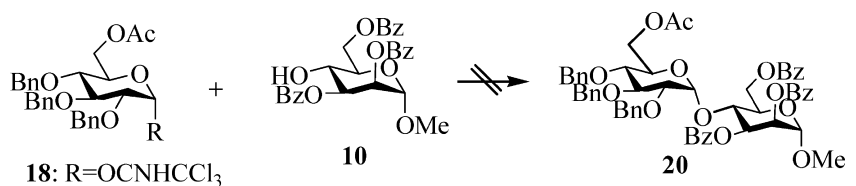

18: $\mathrm{R}=\mathrm{OCNHCCl}$
19: $\mathrm{R}=\mathrm{SCH}\left(\mathrm{CH}_{3}\right)_{2}$

PLATFORM mass spectrometer using the ESI $(-)$ technique to introduce the sample. Thin-layer chromatography (TLC) was performed on silica gel $\mathrm{HF}_{254}$ with detection by charring with $30 \%$ (v/v) $\mathrm{H}_{2} \mathrm{SO}_{4}$ in $\mathrm{MeOH}$ or in some cases by UV detector. Column chromatography was conducted by elution of a column of silica gel (100-200 mesh) with EtOAc-petroleum ether $\left(60-90{ }^{\circ} \mathrm{C}\right)$ as the eluent. The solutions were concentrated at $<60^{\circ} \mathrm{C}$ under reduced pressure.

General Synthetic Procedure for Compound 5. To a solution of levoglucose $\mathbf{3}(2.0 \mathrm{~g}, 12.35 \mathrm{mmol})$ in DMF $(20 \mathrm{~mL})$ at $0{ }^{\circ} \mathrm{C}$ was added $\mathrm{NaH}(1.77 \mathrm{~g}, 74.07 \mathrm{mmol})$, and the mixture was stirred at $0{ }^{\circ} \mathrm{C}$ for 30 $\mathrm{min}$, then $\mathrm{BnBr}(5.90 \mathrm{~mL}, 49.38 \mathrm{mmol})$ was added. The mixture was stirred at $\mathrm{rt}$ for $2 \mathrm{~h}$. The reaction mixture was diluted with cold water $(50 \mathrm{~mL})$ and extracted with EtOAc $(150 \mathrm{~mL})$. The organic phase was dried over anhydrous $\mathrm{Na}_{2} \mathrm{SO}_{4}$ and concentrated. The residue was purified by column chromatography ( $4: 1$ petroleum-EtOAc) to give intermediate 4 (4.96 g, 93\%) as a foamy solid. Solid 4 (4.5 g, 10.42 $\mathrm{mmol})$ was dissolved in dry $\mathrm{CH}_{2} \mathrm{Cl}_{2}(40 \mathrm{~mL})$ and $\left(\mathrm{CH}_{3}\right)_{2} \mathrm{CHSH}(2.83$ $\mathrm{mL}, 31.25 \mathrm{mmol}), \mathrm{BF}_{3} \cdot \mathrm{Et}_{2} \mathrm{O}$ (2.64 $\left.\mathrm{mL}, 20.83 \mathrm{mmol}\right)$ was added, and the mixture was refluxed for $1.5 \mathrm{~h}$. The reaction mixture was neutralized with saturated aq $\mathrm{NaHCO}_{3}$, then extracted with $\mathrm{CH}_{2} \mathrm{Cl}_{2}$. The organic layer was dried and concentrated. Purification of the crude product by column chromatography (4:1 petroleum-EtOAc) gave 5 (2.97 g, 56\%) as a foamy solid.

General Synthetic Procedure for Compounds 2-4. Levoglucose was benzoylated following a reported literature procedure (12), and the following step was the same as the description in the procedure for making compound $\mathbf{5}$. Compounds $\mathbf{9}$ and $\mathbf{1 0}$ were prepared following reported literature procedures $(12,13)$.

Synthetic Procedure for the Coupling Reaction. Donor and acceptor were dried together under high vacuum for $1 \mathrm{~h}$, then dissolved in anhydrous $\mathrm{CH}_{2} \mathrm{Cl}_{2}$ with $\mathrm{N}_{2}$ protection. TMSOTf (or TMSOTf /NIS) was added at $-20{ }^{\circ} \mathrm{C}$, and the mixture was stirred for $20 \mathrm{~min}$ at $-20{ }^{\circ} \mathrm{C}$. TLC indicated that the reaction was complete. The reaction mixture was then neutralized with $\mathrm{Et}_{3} \mathrm{~N}$ and concentrated under reduced pressure to dryness and purification of the crude product by column chromatography. The ${ }^{1} \mathrm{H}$ NMR of compounds 5-17 are listed in Table $\mathbf{1 .}$.

Bioassay. Maize seeds were immersed in $10 \% \mathrm{H}_{2} \mathrm{O}_{2}$ (wt/wt) solution for $10 \mathrm{~min}$ to avoid bacterium contamination and then in $0.1 \mathrm{M} \mathrm{CaCl}_{2}$ for $30 \mathrm{~min}$ to improve germination. Seeds were subsequently germinated on moist filter paper in the dark at room temperature. Two days later, the pregerminated seedlings with seminal leaves were transferred to nutrient media containing $2.0 \mathrm{mM} \mathrm{Ca}\left(\mathrm{NO}_{3}\right)_{2} \cdot 4 \mathrm{H}_{2} \mathrm{O}, 2.5 \mathrm{mM} \mathrm{KNO} \mathrm{KN}_{3}$, $0.5 \mathrm{mM} \mathrm{KH}_{2} \mathrm{PO}_{4}, 1.0 \mathrm{mM} \mathrm{MgSO}{ }_{4} \cdot 7 \mathrm{H}_{2} \mathrm{O}, 0.5 \mathrm{mM} \mathrm{NH}_{4} \mathrm{NO}_{3}, 0.05 \mathrm{mM}$ $\mathrm{FeSO}_{4} \cdot 7 \mathrm{H}_{2} \mathrm{O}, 0.83 \mathrm{mg} / \mathrm{L} \mathrm{KI}, 8.6 \mathrm{mg} / \mathrm{L} \mathrm{ZnSO}_{4}, 6.2 \mathrm{mg} / \mathrm{L} \mathrm{H}_{3} \mathrm{BO}_{3}, 0.25$ $\mathrm{mg} / \mathrm{L} \mathrm{Na}_{2} \mathrm{MoO}_{4}, 22.3 \mathrm{mg} / \mathrm{L} \mathrm{MnSO}{ }_{4}, 0.025 \mathrm{mg} / \mathrm{L} \mathrm{CuSO}_{4}$, and 0.025 $\mathrm{mg} / \mathrm{L} \mathrm{CoCl}$. After the plants had grown for 3 days, the media were then supplemented with oligosaccharides at $3 \mathrm{ppm}$. The media were exchanged every day for fresh media containing oligosaccharides. At the 7th and 21st day of plant growth, plants were wiped with tissue paper and weighed (18-20). The role of oligosaccharides in growth regulation is described in Figures 1-3.

\section{RESULTS AND DISCUSSION}

Synthesis. Compounds 5 and $\mathbf{7}$ were synthesized efficiently using 1,6-anhydro- $\beta$-D-glucose (levoglucose), which was prepared through pyrolysis of wasted cotton in our laboratory, as the starting material. Nucleophilic attack on C-1 of protected levoglucose by 2-propanethiol, with the help of boron trifluoride etherate, significantly simplified the whole strategy as shown in Scheme 2. Compounds 11-17 were prepared in good yield as shown in Schemes $\mathbf{4}$ and $\mathbf{5}$.

Initially, we attempted to make the desired disaccharide $\mathbf{2 0}$ via a coupling reaction of 6- $O$-acetyl-2,3,4-tri- $O$-benzyl- $\alpha$-Dglucopyranosyl trichloroacetimidate (18) and 10, but failed. Only decomposed 18 and unreacted 10 were found in the reaction mixture. A condensation of isopropyl 6- $O$-acetyl-2,3,4-tri- $O$ benzyl-1-thio- $\alpha$-D-glucopyranoside (19) and 10 was also tried, but was fruitless (Scheme 6). It is thus believed that active glycosyl donor does not match with the unreactive acceptor in our design strategies (21). Fortunately, a relatively inactive disaccharide donor 11 was matched with 10; thus, we obtained the desired trisaccharide $\mathbf{1 2}$ under the same reaction conditions.

Effects on the Growth of Maize Plants. The results of growth regulation activity tests given in Figures 1-3 show that synthetic pentasaccharide and heptasaccharide promote the growth of maize plants and also stimulate the growth of roots. After supplementing with oligosaccharides for a week, pentasaccharide increased the mass of plants by $21.4 \%$, while heptasaccharide increased the mass of plants by $10.7 \%$. When supplemented with oligosaccharides for 3 weeks, pentasaccharide improved by $23.6 \%$, and heptasaccharide improved by $32.7 \%$. We also tested the effects of different concentrations of oligosaccharides ( $3 \mathrm{ppm}, 6 \mathrm{ppm}$, and $9 \mathrm{ppm}$ ) on the growth of plants and found that high concentration did not improve the growth rate more.

Table 2. Chemical Characteristics of Compounds 1 and 2

\begin{tabular}{|c|c|c|}
\hline characteristics & compd 1 & compd 2 \\
\hline $\begin{array}{l}{ }^{1} \mathrm{H} \text { NMR chemical shift } \delta \text { (ppm) } \\
{ }^{13} \mathrm{C} \text { NMR chemical shift } \delta \\
\text { (ppm) } \\
\text { ESI(+)-MS }\end{array}$ & $\begin{array}{l}4.31-4.40\left(\mathrm{H}_{1}^{\prime}, \mathrm{H}_{1}{ }^{\prime \prime}, \mathrm{H}^{\mathrm{III}}\right), 5.08\left(\mathrm{H}_{1}^{\mathrm{IV}}\right), 4.62\left(\mathrm{H}_{1}^{\mathrm{V}}\right) \text {, } \\
3.30\left(\mathrm{OCH}_{3}\right) \\
102.6-103.0\left(\mathrm{C}_{1}{ }^{\prime}, \mathrm{C}_{1}{ }^{\prime \prime}, \mathrm{C}_{1}{ }^{\prime \prime \prime}\right), 100.7\left(\mathrm{C}_{1}{ }^{\mathrm{IV}}\right), 100.0 \\
\left(\mathrm{C}_{1}{ }^{\mathrm{V}}\right) \\
\text { calcd for } \mathrm{C}_{31} \mathrm{H}_{54} \mathrm{O}_{26}: 842.29 \\
\text { found } 860\left[\mathrm{M}+\mathrm{NH}_{4}\right]^{+}, 865[\mathrm{M}+\mathrm{Na}]^{+}\end{array}$ & 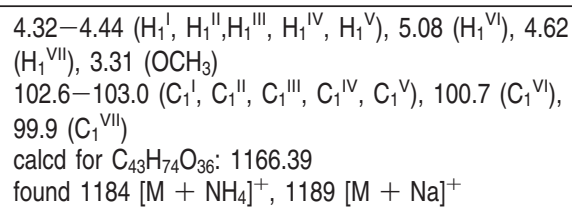 \\
\hline
\end{tabular}


In this article, we first synthesized pentasaccharide and heptasaccharide derivatives $\mathbf{1}$ and $\mathbf{2}$. At present, there have been no related reports about their plant growth activity. In the bioassay, plant auxins such as 2,4-dichlorophenoxyacetic acid and indole-3-acetic acid were used for positive control, but in our experimental conditions, 2,4-dichlorophenoxyacetic acid inhibited maize growth at a concentration of $3 \mathrm{ppm}$, and indole3 -acetic acid did not have any effects on the growth of maize at $3 \mathrm{ppm}$. The effect of glucose on maize growth was also tested, but it did not have any effect at this concentration. Compared with the known plant auxins, synthesized oligosaccharides may have different mechanisms affecting the growth of maize.

\section{ACKNOWLEDGMENT}

We thank Drs. Shuzhen Zhang and Yanhong Zhu from RCEES of CAS for their helpful discussions.

\section{LITERATURE CITED}

(1) Sharp, J. K.; McNeil, M.; Albersheim, P. The primary structure of one elicitor-active and seven elicitor-inactive hexa( $\beta$-D-glucopyranosyl)-D-glucitols isolated from the mycelial walls of Phytophthora megasperma f. sp. glycinea. J. Biol. Chem. 1984, 259, 11321-11326.

(2) Darvill, A. G.; Alberseim, P. Phytoalexins and their elicitors-a defense against microbial infection in plants. Annu. Rev. Plant Physiol. 1984, 35, 243-275.

(3) Cheong, J.-J.; Birberg, W.; Fugedi, P.; Pilloti, A.; Garegg, P. J.; Hong, N.; Ogawa, T.; Hahn, M. G. Structure-activity relationships of oligo- $\beta$-glucoside elicitors of phytoalexin accumulation in soybean. Plant Cell 1991, 3, 127-136.

(4) Fry, S. C.; Aldington, S.; Hetherington, P. R.; Aitken, J. Oligosaccharides as signals and substrates in the plant-cell wall. Plant Physiol. 1993, 103 (1), 1-5.

(5) Creelman, R. A.; Mullet, J. E. Oligosaccharins, brassinolides, and jasmonates: Nontraditional regulators of plant growth, development, and gene expression. Plant Cell 1997, 9 (7), 1211-1223.

(6) Yuan, K.; Wysocka-Diller, J. Phytohormone signalling pathways interact with sugars during seed germination and seedling development. J. Exp. Bot. 2006, 57 (12), 3359-3367.

(7) Zabotina, O. A.; Gurjanov, O. P.; Ibragimova, N. N.; Ayupova, D. A.; Lozovaya, V. V. Rhizogenesis in buckwheat thin-cell-layer explants: effect of plant oligosaccharides. Plant Sci. 1998, 135 (2), 195-201.

(8) Albersheim, P.; Darvill, A.; Augur, C.; Cheong, J. J.; Eberhard, S.; Hahn, M. G.; Marfa, V.; Mohnen, D.; Oneill, M. A.; Spiro, M. D.; York, W. S. Oligosaccharins: Oligosaccharide regulatory molecules. Acc. Chem. Res. 1992, 25 (2), 77-83.

(9) Zhou, L. A.; Yang, C. Z.; Li, J. Q.; Wang, S. L.; Wu, J. Y. Heptasaccharide and octasaccharide isolated from Paris polyphyllavar. yunnanensis and their plant growth-regulatory activity. Plant Sci. 2003, 165 (3), 571-575.
(10) Zhou, L.; Cao, X.; Zhang, R.; Peng, Y.; Zhao, S.; Wu, J. Stimulation of saponin production in Panax ginseng hairy roots by two oligosaccharides from Paris polyphylla var. yunnanensis. Biotechnol. Lett. 2007, 29 (4), 631-4.

(11) Zhuang, X. L.; Zhang, H. X.; Yang, Z. G.; Qi, H. Y. Preparation of levoglucosan by pyrolysis of cellulose and its citric acid fermentation. Biores. Technol. 2001, 79, 63-66.

(12) Ning, J.; Yi, Y. T.; Kong, F. Z. A general strategy for the synthesis of 3,6-branched gluco-oligosaccharides: facile synthesis of the phytoalexin elicitor oligosaccharides. Tetrahedron Lett. 2002, 43 (32), 5545-5549.

(13) Zhao, W.; Kong, F. Z. Synthesis of a heptasaccharide fragment of the O-deacetylated GXM of C-neoformans serotype C. Carbohydr. Res. 2005, 340 (10), 1673-1681.

(14) Gu, G.; Wei, G.; Du, Y. Synthesis of a 6(V)-sulfated mannopentasaccharide analogue related to PI-88. Carbohydr. Res. 2004, 339 (6), 1155-62.

(15) Adinolfi, M.; Barone, G.; Iadonisi, A.; Schiattarella, M. Removal of benzyl protecting groups from controlled pore glass linked sugars. Tetrahedron Lett. 2001, 42 (34), 5971-5972.

(16) Gemma, E.; Lahmann, M.; Oscarson, S. Synthesis of the tetrasaccharide a-D-Glcp-( $1 \rightarrow 3)$-a-D-Manp-( $1 \rightarrow 2)$-a-D-Manp-( $1 \rightarrow 2)$-a-DManp recognized by calreticulin/calnexin. Carbohydr. Res. 2005, 340 (16), 2558-62.

(17) Adinolfi, M.; Barone, G.; Guariniello, L.; Iadonisi, A. Facile cleavage of carbohydrate benzyl ethers and benzylidene acetals using the $\mathrm{NaBrO}_{3} / \mathrm{Na}_{2} \mathrm{~S}_{2} \mathrm{O}_{4}$ reagent under two-phase conditions. Tetrahedron Lett. 1999, 40 (48), 8439-8441.

(18) Peralta, J.; Gardea-Torresdey, L. Study of the Effects of Heavy Metals on Seed Germination and Plant Growth on Alfalfa Plant (Medicago sativa) Growth in Solid Media. Proceedings of the 2000 Conference on Hazardous Waste Research; Great Plains/ Rockey Mountain Hazardous Substane Research Center: Manhattan, $K S$.

(19) Kollarova, K.; Henselova, M.; Liskova, D. Effect of auxins and plant oligosaccharides on root formation and elongation growth of mung bean hypocotyls. Plant Growth Regul. 2005, 46 (1), 19.

(20) Sandalio, L. M.; Dalurzo, H. C.; Gomez, M.; Romero-Puertas, M. C.; del Rio, L. A. Cadmium-induced changes in the growth and oxidative metabolism of pea plants. J. Exp. Bot. 2001, 52 (364), 2115-2126.

(21) Zhang, Z; Ollmann, I. R.; Ye, X; Wischnat, R.; Baasov, T.; Wong, C. Programmable one-pot oligosaccharide synthesis. J. Am. Chem. Soc. 1999, 121, 734-753.

Received for review February 20, 2008. Revised manuscript received April 27, 2008. Accepted May 5, 2008. This work is supported by NNSF 20572128 and SKLECE Foundation, China.

JF800326R 